DOI: https://doi.org/10.32839/2304-5809/2019-5-69-26

UDC 811.111

Yakushko Kateryna, Petrenko Myroslava

National University of Life and Environmental Sciences of Ukraine

\title{
THE STAGES TO INVOLVE THE ENGLISH STATEMENTS IN ORDER TO DISCUSS THE ACHIEVEMENTS OF AGROCHEMISTRY
}

Summary. Relevance of the study is to describe the practice of linguistic studies on the practical professionally oriented English lessons and to identify the stages of gradual engagement of English expressions during a dialogue-discussion to discuss the potential of biofuels as a topical agrochemical topic. The main conclusions: the inclusion of English expressions into the conclusion of the dialogue is appropriate to carry out in stages; the main stages are: 1) familiarization and narrowing of the actual professional topics to general one, at which simultaneously several reports are prepared; 2) clarification of the plan, vocabulary, key questions and answers of each of the participants in the future dialogue to avoid coincidences; 3) preliminary formal general dialogue start with constant colloquial cliche; 4) the actual entry into the dialogue according to a specific topic; 5) providing dialogue with the elements of the discussion; 6) a reversible asking to specify unpublished pre-prepared items; 7) the formal general ending of the conversation with the stable conversational cliches. The experience to involve the abovenamed algorithm may be considered to be successful because of the adequate questionnaire in which spudents evaluated such experience as positive to adapt them to foreign speech. The prospect of research is a description of the experience to involve English statements while discussing reports on adjacent agrochemical, agronomic or technical topics on the practical professionally oriented English lessons at the National University of Life and Environmental Sciences of Ukraine.

Keywords: English statement involvement, stages to conclude dialogue, communicative cliche, discussion, report-presentation, professionally oriented English, actual agrochemical theme, biofuels.

Якушко К.Г., Петренко M.I. Національний університет біоресурсів і природокористування України

\section{ЕТАПИ ЗАЛУЧЕННЯ АНГЛІЙСЬКИХ ВИСЛОВІВ ДЛЯ ОБГОВОРЕННЯ ДОСЯГНЕНЬ АГРОХІМІЇ}

Анотація. На даний час важливого значення набирає розробка алгоритмів змістового наповнення іншомовних комунікативних висловів задля оптимізації обговорення певних сучасних пристроїв або технологій під час вивчення іноземної мови за професійним спрямуванням студентами різних напрямів агробіологічної підготовки. Актуальність проведеного дослідження - у описі практики здійснення мовознавчих студій на практичних заняттях з англійської мови за професійним спрямуванням та визначенні етапів поступового залучення англійських висловів під час складання діалогу-дискусії для обговорення потенціалу біопалива як актуальної агрохімічної тематики. Основні висновки: залучення англійських висловів при укладанні діалогу доречно здійснювати поетапно; основними етапами $є: 1)$ ознайомлення та звуження актуальної професійної тематики до спільної одніеї, за якою водночас готуються кілька доповідей; 2) уточнення плану, словника, ключових запитань та відповідей кожного з учасників майбутнього діалогу для уникнення збігів; 3) попередне формальний загальний початок діалогу з сталими розмовними кліше; 4) власне входження в діалог специфічної тематики; 5) надання діалогу елементів дискусії; 6) зворотне опитування для уточнення неоголошених заздалегідь підготовлених пунктів; 7) формальне загальне закінчення виступу з сталими розмовними кліше. У статті унаочнено зазначені деталі на прикладах. Конкретизацією першого етапу залучення англійських висловів для обговорення досягнень агрохімії стало опитування студентів щодо їх пропозищій: в результаті мозкового штурму була обрана тема» досягнення агрохімії через паралельну підготовку двома студентами тем «Біопаливо» та «Біогаз» як синтезуюча розроблені доповіді, а другого - уточнення плану через зазначення таких пунктів, як значення, структура, переваги застосування, агрегатні стани, економічність та уточнення відповідного термінологічного апарату по кожному пункту на кшталт «біопаливо», «біогаз», «рідини», «копалини» тощо. Двома учасниками на другому етапі діалогу заздалегідь підготовлені відповіді на запитання кожного щодо своєї презентації на кшталт «рідинні, газоподібні, блокові» на запитання «Які фрорми відпуску біопалива?». Конкретизаціею третього етапу залучення англійських висловів для обговорення досягнень агрохімії стало вживання висловів на кшталт «Радий Вас бачити...», «Давайте обговоримо...», «Яка Ваш науковий інтерес?» тощо, а четвертого - представлення вузькопрофрільних фрактів зі сфери агрохімії на кшталт «Передбачається, що площа посівів рослин для отримання сировини біопалива до 2030 може займати більше 30 млн га». Конкретизацією п'ятого етапу залучення англійських висловів для обговорення досягнень агрохімії стало надання діалогу елементів дискусії завдяки виростанню виразів на кшталт «Я мабуть не зможу погодитися з Вами, що...», «Чи це сприятиме збереженню довкілля?» тощо, а шостого - представлення підготовлених на другому етапі запитань та відповідей через попередне уточнення «Чи могли б Ви пояснити специфічні пункти на кшталт різновидів форм відпуску біопалива?» Останній сьомий етап оперував залученням таких висловів, як « Дякую за відповіді», «Було цікаво», «Я дізнався нове про біогаз та біопаливо», «До наступної зустрічі» як прикладів формального загального закінчення виступу з сталими розмовними кліше. Вважаємо, що запропонований алгоритм адаптував входження в іншомовне середовище агробіологів як представників немовних спеціальностей, оскільки анкетування студентів показало визнання його як позитивного. Перспективами дослідження є опис досвіду залучення англійських висловів при обговоренні доповідей і технічної або суто агрономічної тематики на практичних заняття з англійської мови за професійним спрямуванням у Національному університеті біоресурсів і природокористування України.

Ключові слова: залучення англійських висловів, етапи укладання діалогів, комунікативні кліше, обговорення, доповідь-презентація, англійська мова за професійним спрямуванням, актуальна агрохімічна тема, біопаливо. 
Tntroduction. Nowadays it is important to develop a sequence of contents of English language communicative expressions in order to optimize the discussion of report-presentation about some concrete adequate devices or technologies while studying professionally oriented foreign language by the students of the various fields of agrobiological or technical training [2]. The purpose is to describe the stages to involve English statements during the concluding of dialogue to discuss the actual agrochemical problem on the practical lessons of professionally oriented English as the practical experience during the real studying process. To solve above named task such methods as analysis, systematization and generalization were applied as well as the method of practical experience presentation.

Results and discussion. First of all, basing upon the experience of practical application of the communicative statements content algorithmization during the preparation for foreign language practical lessons at the National University of Life and Environmental Sciences of Ukraine, each future dialogue participant should choose one the most actual problem within a certain field of agronomic knowledge, to narrow the circle of scientific interest in gathering facts and illustrations in relation to a particular theme for example concerning determining the features of biofuels potential. On this stage each future dialogue participant should elaborate his own presentation concerning the general group topic with a detailed description of a certain latest equipment or technology that will be of interest either to professionals in a certain area of agrochemistry or to the general public. On this stage each future dialogue participant should print out the main points with illustrations and a vocabulary of basic concepts. This first step is considered to be very important preparatory stage for the further conclusion of dialogue in accordance with the colloquial situation "Your are the members of scientific society. Represent your scientific interest and describe the structure of your presentation» [1].

The second step is to review the guidelines for selecting the second participant in the dialogue with identical scientific interest. At the specified stage of the discussion of achievements, two relevant presentations about biofuels must be concluded. Please, pay attention that their content, vocabulary should not be repeated by another future dialogue participant. For the implementation of the indicated instruction between these two future dialogue participants, the emphasis is to be placed on the use of such lexical units as "biofuels - біопаливо", "digestion - pозщеплення", "residues - залишки, відxодu", "soybean - coя", "реllets - гранули", "lumber - пилолатеріали", "сrорs - зернові культури", "biodegradable - той, шо розкладається природніл шляхол", "fossil-копалини", "recycled - nерероблений», "етissions - викидu», "feedstocks - cuровина" еtc. [3], [4]. According to the task to discuss the value of biofuels, a plan of reports about biofuels for the first participant should be updated on such items as "1) Biofuels as a term"; "2) The sources to obtain biofuels"; "3) The difference between ethanol and biodiesel" and for the second participant it should be updated on such items as "1) The nature of biogas"; "2) Pallets"; "3) Liquids". Also the future dialogue participants should preview content of each presentation and they should prepare some previous answers to specific questions. The previous review of replicas to be checked by the first dialogue participant should predict such previous answer as "A biofuel is a fuel that is produced through biological processes, such as agriculture and anaerobic digestion, rather than a fuel produced by geological processes (coal or petroleum)" for the question "What are biofuels?". Besides, the context may be specified by the first student with the answer"Yes, it is" for the question "Is biological fuel a safe alternative to existing vehicle engines?" and "Biofuels technology is capable of reducing greenhouse gas emissions and for the use of fossil fuels, is not it?" as well as "Is biofuel produced from renewable biomass material, commonly used as an alternative, cleaner fuel source to burning fossil fuels?" and "Is it difference between ethanol and biodiesel?" with the appendix in answer like "Ethanol is a flam mable and renewable liquid produced by the fermentation of grain or from advanced technology such as agricultural waste, wood chips and waste paper. And biodiesel is produced through a combination of alcohol with recycled cooking grease, animal fat or vegetable oil» and the answer "No, they are not" for the question "Are biofuels high in carbon intensity?". This first participator of discussion must choose the most interesting questions among the above named list to be asked. The second participant of the dialogue in his own turn must choose his own five the most interesting answers among the answer "The process of anaerobic digestion of organic material by anaerobes leads to biogas. The use of energy crops fed into anaerobic digesters to supplement gas yields" for the question "What leads to biogas?", the answer "Grain, crop residue, cellulosic crops (e.g., switch grass, sugar canes and various tree species) are used for the production of biofuel. These products are processed further to generate liquid fuels such as ethanol or diesel fuel. These fuels release $\mathrm{CO} 2$ when burned, but this CO2 is of recent atmospheric origin (via photosynthesis) and displaces CO2 which otherwise would have come from fossil carbon" for the question "What materials are used to produce biofuels?" and the answer "They may be in solid form like pellets in gaseous form like biogas and in liquid state as biodiesel» for the question "What are the main kinds of biofuels?" as well as the answer "They are usually made from compressed industrial waste and co-products, food waste, agricultural residues, lumber, energy crops" for the question "What are the features of pellet fuels (or pellets)?» $[5 ; 6]$.

The next stage is to transform common dialoque into discussion. Following it every participant must get positive or negative attitude to biofuel usage choosing arguments among advantages or disadvantages. The first discussion participant may choose his arguments by shotering the provement of advantges on his own mind: "Unlike fossil fuel, biofuels are produced from renewable resources. Also there are less pollutant emissions from biofuels. Ethanol reduces carbon monoxide emissions as it ensures complete combustion. Besides, biofuel do not contribute to global warming as carbon dioxide released, is taken up by their feedstocks. There are also some advantages in some statements like biofuels are cost-efficient when compared to fossil fuels and some of the biofuels producing plants like Jatropha and oil-palms can be grown in dry land 
and fallow area. Also about 70-88 million biogas plants can be run with fresh/dry biomass residues. The substrate such as cattle waste and biomass used for this technology are easily available. Their availability to biogas plants can meet the requirement of 12-30 million families. The calculated global potential of biogas production is in theory sufficient to cover up to one-fourth of the present consumption of fossil fuels within the global transport sector. Using it within agriculture could reduce agriculture's dependency on fossil energy, improving food security. Making biofuels is a profitable process not only for the economy but for the environment. We can use this kind of fuels for agricultural machinery".

The second discussion participant may choose his arguments by shotering the provement of disadvantges on his own mind: "A larger area of land will be required to satisfy global biofuels demand. Projected growth of biofuels crops until 2030 may require over 30 million hectares of land. In many cases for current ethanol production from grain, the fossil fuel associated with use of chemical fertilizers, tractor power and so on, results in an unacceptably small net reduction in fossil fuel use. Besides, production systems with suitable enzymes for utilizing cellulosic feedstocks have not yet become commercially viable. Also it should be mentioned that the resources for biogas generation are not properly managed to generate its maximum biogas potential. Besides, the lack of availability and the structural operation of biogas digesters are not able to generate and develop family-size biogas plants. Despite our country has many resources to create a biofuels but we have some problems with funding" [7].

The next stage to involve English expressions into dialogue- discussion should be immediate introduction of it, starting with the indication of their roles, the greetings and the purpose of the communication: definition in such phrases as "I'm one member of scientific (sphere of knowledge) society and you are another scientist", "Hello. Nice to meet you", "Hi, nice to meet you too. Can I help you?", "Yes, you can. Let us discuss our reports", "You are welcome. What are you interested in?». On this stage future dialogue participants should be guided by a thematic approach to involve common English statements with some spaces for continuation basing upon explanation in brackets : "What is your scientific interest?", "I'm interested in (the title of presentation)", "What is the structure of your report?", "It is in the form of presentation to include (quantity) slides", "What is your plan?", "The main points are (noting the points of the plan of the pre-prepared presentation)", "What are your main terms from vocabulary?", "They are (preprepared vocabulary)", "What are the most actual phenomenon to be represented?" (noting the title of preprepared presentation), "What are their usage and advantages?" noting advantages from preprepared explanation), "They are (preprepared theses)", "Is your topic important?", "Yes, it is. It is important because (explanation involving the answers to preprepared questions)".

The elements of discussion may predict such phrases as "I'm afraid I can no agree», Is it good for environmental safety?» etc. The next stage is the reversible answering to specify the unannounced points by involving some English statements to be prepared by the second dialogue participant with the pre-stage addition "Will you be so kind to explain the specific points like the forms of biofuels?" The last stage is the final one to require the completion of the conversation in certain statements like "Well, I'm interested in your report", "Thanks for your interest. Your report is important too. See you while reporting", "Bye" to finish conversation.

In our opinion, the submitted order of English statements involvement optimized the work of agrobiological direction students while preparation for discussion of reports-presentation of the latest technologies in the relevant field of knowledge. The experience to involve the abovenamed algorithm may be considered to be successful because of the adequate questionnaire in which spudents evaluated such experience as positive to adapt them to foreign speech.

Conclusions. Thus, the inclusion of English expressions into the conclusion of the dialogue is appropriate to carry out in stages; the main stages are: 1) familiarization and narrowing of the actual professional topics to general one, at which simultaneously several reports are prepared; 2) clarification of the plan, vocabulary, key questions and answers of each of the participants in the future dialogue to avoid coincidences; 3) preliminary formal general dialogue start with constant colloquial cliche; 4) the actual entry into the dialogue according to a specific topic; 5) providing dialogue with the elements of the discussion; 6) a reversible asking to specify unpublished pre-prepared items; 7) the formal general ending of the conversation with the stable conversational cliches. The prospect of research is a description of the experience to involve English statements while discussing reports on adjacent agrochemical, agronomic or technical topics on the practical professionally oriented English lessons at the National University of Life and Environmental Sciences of Ukraine.

\section{References:}

1. Ponomarenko O.H., Berezova L.V., Yakushko K.H. and others (2018). Integrated Technical English Course: P. 1 «Bachelor's Course». Kyiv : Ekspodruk.

2. Yakushko K.H. (2017). Pedahohochni umovy formuvannia profesijno-orijentovanoho inshomovnoho spilkuvannia $\mathrm{u}$ studentiv tekhnichnykh spezialnostej ahrarnykh universytetiv [Pedagogical conditions for acquiring professionally oriented other language communication by students of technical fields within agrarian universities]. Kyiv : Komprynt. (in Ukrainian)

3. Pellet Fuel (2011). Available at: https://en.m.wikipedia.org/wiki/Pellet_fuel

4. Biofuel (2012). Available at: https://en.m.wikipedia.org/wiki/Biofuel

5. Farm energy (2015). Available at: https://articles.extension.org/pages/26625/miscanthus-miscanthus-x-giganteusfor-biofuel-production

6. Kris Walker (2013). What is Biofuel? Available at: https://www.azocleantech.com/article.aspx?ArticleID=329

7. Kersi Johansson, Karin Liljequist, Lars Ohlander, Kjell Aleklet (2010). Agrigulture as a provider of both food and fuel. Available at: https://www.ncbi.nlm.nih.gov/pmc/articles/PMC3357690 